UDK: 351.74:377(438)

\title{
PRACTICAL USE OF OFFICERS OF POLICE FORCES AS TEACHERS IN THE PROCESS OF EDUCATION FOR INTERNAL SECURITY. MODELS OF A 'ROTATIONAL POST' AND 'ASSOCIATE LECTURER'
}

\author{
Piotr Bogdalski* \\ Police Academy in Szczytno, Poland
}

\begin{abstract}
The article presents the issue of a model of a temporary use of local police units' officers as police teachers. In the Polish Police in 2011, the issue of introducing special teaching 'rotational posts' to police training centres, which would be held by officers of local police units for several years, was discussed. The Chief of the Polish Police formed a team the aim of which was to decide on the underlying principles of the idea. The team's result, however, aroused controversy. Simultaneously, the alternative was suggested that the already functioning practice model of an 'associate teacher' in the police should be further developed, which was finally accepted by the Chief of the Polish Police. The changes implemented by him definitely improved the effectiveness of the existing model. The trend was clearly noticed in the first three quarters of the 2013 year.
\end{abstract}

Keywords: police teacher, associate lecturer/teacher, the police, education system

\section{Introduction}

The necessity of a temporary employment of officers of local police forces as teachers in the police education system is fully justified and has already been under discussion several times. ${ }^{2}$ However, this study will be focused on the issue of choosing the best legal and organisational model, which makes it possible to

* p.bogdalski@wspol.edu.pl

2 More: P. Bogdalski, Сотрудники отделений полиции в качестве внештатных преподавателей в высших полицейских учебных заведениях. In: Вестник Академии МВД Республики Беларусь, АкадемияМВДРеспубликиБеларусь,Мінск,No.2(22),2011,pp.214-219.Criticalopinions, however, shouldalsobetakenintoconsideration.Quotinganexample, apersondoesnothavetobeaddictedinorderto teachtheissuesofaddictions.(B.L.Berg,PolicinginModernSociety,Butterworth/Heinemann,Boston,1999, pp. 435,436 ). 
transfer knowledge and skills of officers from local police units to police schools. Nevertheless, it must be taken into consideration that in every police force numerous individual factors work in favour of a particular solution. The process will be described further in the text, as a result of which a model of temporary employment of local police units' officers as police teachers was developed. It may serve as a point of reference for other police forces which are willing to modify or work out their own solutions in this respect.

In the Polish Police up to 2011 there had been no projects carried out which would define legal and organisational frameworks for employing police officers from local units as police teachers. In fact, such practice was applied but it was mainly based on general internal rules of an organisation. They made it possible to support a certain police unit by a temporarily seconded police officer of another unit. Police training centres took this advantage incidentally as a part of an effective cooperation with local police units.

The above problem was identified by the Polish Police Chief who then considered bringing about far-reaching changes in the discussed area. This was about introducing a model of rotational teachers into the police education system. In practice this would concern experienced officers of local police units who would be seconded for a few years' period of time to training centres. After this period they would come back to their original place of work. ${ }^{3}$ For that reason, the Chief of the Polish Police established a team the aim of which was to work out solutions in the area of temporary employment of police officers on police teachers' positions. ${ }^{4}$ Under the Decision, the fundamental tasks of the Team were as follows:

1) To provide facts and figures in the area of employing police officers temporarily for positions of police teachers at the Police Academy in Szczytno and in police schools;

2) To define the competitiveness of police teachers' posts and their equivalent positions in other police units; and,

3) To develop motivation mechanisms and forms of temporary employment of police officers on posts of police teachers.

\section{General description of teaching personnel in police training centres}

\subsection{Number of police teaching staff members}

Considering the number of police teaching positions, there are bigger police training centres (the Police Training Centre in Legionowo, the Police Academy in Szczytno, the Police School in Słupsk) and considerably smaller ones (the Po-

3 Similar solutions are applied in several European police higher education institutions. (More: P. Bogdalski, Survey on the Teaching Staff of European Police Colleges. In: Internal Security, 2009. Szczytno: Police Academy, No 1, s. 154 i n.).

4 PolishPoliceChief'sDecisionof2May2011,No.160. TheheadoftheTeamwastheauthorofthepresent paper.Moreover, its participantswerealso the representatives of the NationalPoliceHeadquartersand of policetrainingcenters,i.e.:W.Majchrowicz,L.Ptach,E.Szydłowska,R.Stanisławski,T.Wewiór,A.Giland D. Kotus. 
lice School in Katowice and the Police School in Piła) in Poland. The team of the National Police Chief assumed that the rotation process ought to concern only a relatively small number of teaching positions. Simultaneously, this number of positions which police officers would hold temporarily (rotational posts) could not be the same for all training units. In this case an appropriate percentage rate ought to be applied. It would be a ratio of a number of rotational posts to an overall number of police teaching positions.

It should be emphasized here that there is a significant disproportion between particular groups of teaching posts in individual job structures of police schools. While in Legionowo and Katowice the number of low-ranking posts (instructor, junior lecturer) is equal to high-ranking posts (lecturer, senior lecturer), the schools in Piła and Słupsk have more high-ranking posts (lecturer and senior lecturer). It would be legitimate then to select rotational posts from the group of posts which are dominant in particular school according to the Team's opinion.

Chart 1 - The number of teachers - police officers in particular police training units (as of 1 March 2011)

\begin{tabular}{|c|c|c|c|c|c|c|c|c|c|c|c|}
\hline & & \multicolumn{2}{|c|}{ Szczytno } & \multicolumn{2}{|c|}{ Legionowo } & \multicolumn{2}{|c|}{ Katowice } & \multicolumn{2}{|c|}{ Pila } & \multicolumn{2}{|c|}{ Shupsk } \\
\hline \multirow{7}{*}{$\begin{array}{l}\text { Number of } \\
\text { teachers - police } \\
\text { officers }\end{array}$} & Instructor & 45 & $\begin{array}{l}34.5 \\
\%\end{array}$ & 47 & $30 \%$ & 13 & $19 \%$ & 1 & $1.5 \%$ & 3 & $3 \%$ \\
\hline & Junior lecturer & 0 & $0 \%$ & 47 & $30 \%$ & 20 & $29 \%$ & 10 & $\begin{array}{l}14.5 \\
\%\end{array}$ & 11 & $10 \%$ \\
\hline & $\begin{array}{l}\text { Lecturer/foreign } \\
\text { language teacher }\end{array}$ & 42 & $32 \%$ & 34 & $21 \%$ & 22 & $32 \%$ & 40 & $57 \%$ & 56 & $51 \%$ \\
\hline & Senior lecturer & 36 & $28 \%$ & 30 & $19 \%$ & 14 & $20 \%$ & 19 & $27 \%$ & 40 & $36 \%$ \\
\hline & Assistant professor & 6 & $5 \%$ & 0 & $0 \%$ & 0 & $0 \%$ & 0 & $0 \%$ & 0 & $0 \%$ \\
\hline & Associate professor & 1 & $0.5 \%$ & 0 & $0 \%$ & 0 & $0 \%$ & 0 & $0 \%$ & 0 & $0 \%$ \\
\hline & Total & \multicolumn{2}{|c|}{130} & \multicolumn{2}{|l|}{158} & \multicolumn{2}{|l|}{69} & \multicolumn{2}{|l|}{70} & \multicolumn{2}{|l|}{110} \\
\hline
\end{tabular}

Source: Personnel and Training Bureau, National Police Headquarters

\subsection{Work experience of police teachers}

While discussing the issue of police teachers' work experience one should take two aspects into consideration. First of them is relevant experience, the second one is its validity.

The experience of the Personnel and Training Bureau of the National Police Headquarters suggests that one of the requirements that a candidate for a police teacher should meet is ten-year service at local police units. ${ }^{5}$ Of course, the nature

5 The requirement for work experience from the teacher of profession is not specific for the police only. For example, when teaching how to become a nurse the teacher is required to have at least five years of professional experience in nursing (M. Marć, M. Binkowska-Bury, B. PenarZadarko, Wymagania stawiane nauczycielom zawodu pielęgniarstwa - przeszłość, teraźniejszość, przyszlość. In: Problemy Pielegniarstwa, No 16, 2008, p. 408). On the other hand, in order to link vocational education with its economic environment in 2009 new regulations were added to the Polish Act on Education System. They allow the head of an educational institution to employ people who are not teachers but e.g. specialists in the area. They then obtain the status of a chartered teacher (Ministerstwo Edukacji Narodowej, Kształcenie zawodowe i ustawiczne, Fundacja Fundusz Współpracy, Warszwa, 2010, p. 18). 
of such service should coincide with the range of tasks performed when holding a didactic post. Only then one may assume that a candidate has the work experience suitable for serving at a police training unit.

When analysing the situation of police training units one may state that the most of the teaching staff did not meet the afore-mentioned requirement. In 2011, 76\% of police teaching staff at the police school in Słupsk had up to ten years service at local police units, in Szczytno - 72\%, Legionowo - 69\%, Piła - 66\% and Katowice - 63\%.

Chart 2 - Years of police teaching staff service at local police units

(as of 1 March, 2011)

\begin{tabular}{|c|c|c|c|c|c|c|c|c|c|c|c|}
\hline & & \multicolumn{2}{|c|}{ Szczytno } & \multicolumn{2}{|c|}{ Legionowo } & \multicolumn{2}{|c|}{ Katowice } & \multicolumn{2}{|c|}{ Pila } & \multicolumn{2}{|c|}{ Slupsk } \\
\hline \multirow{6}{*}{$\begin{array}{l}\text { Years of } \\
\text { service at local } \\
\text { police units }\end{array}$} & $0-5$ & 57 & $44 \%$ & 42 & $30 \%$ & 17 & $\begin{array}{l}27.5 \\
\%\end{array}$ & 30 & $47 \%$ & 54 & $\begin{array}{l}51.5 \\
\%\end{array}$ \\
\hline & $6-10$ & 37 & $\begin{array}{l}28.5 \\
\% \\
\end{array}$ & 54 & $39 \%$ & 22 & $\begin{array}{l}35.5 \\
\% \\
\end{array}$ & 12 & $19 \%$ & 26 & $25 \%$ \\
\hline & $11-15$ & 30 & $23 \%$ & 26 & $19 \%$ & 20 & $32 \%$ & 14 & $22 \%$ & 18 & $17 \%$ \\
\hline & $16-20$ & 5 & $4 \%$ & 14 & $10 \%$ & 3 & $5 \%$ & 8 & $12 \%$ & 5 & $4.5 \%$ \\
\hline & $21-25$ & 1 & $0.5 \%$ & 3 & $2 \%$ & 0 & $0 \%$ & 0 & $0 \%$ & 2 & $2 \%$ \\
\hline & More than 25 & 0 & $0 \%$ & 0 & $0 \%$ & 0 & $0 \%$ & 0 & $0 \%$ & 0 & $0 \%$ \\
\hline
\end{tabular}

Source: Data of Personnel and Training Bureau, National Police Headquarters

In order to state whether the experience is valid one should take the CEPOL's stand. ${ }^{6}$ According to it a valid professional experience is possessed by a police teacher who performed his/her police tasks outside the training unit for the last five years.

Taking the above-mentioned criterion into consideration, it may be stated then that in 2011 the situation in police training units was similar. In four of them (Szczytno, Legionowo, Piła and Słupsk) not much more than $30 \%$ of police teaching staff possessed valid professional experience. In case of the police school in Katowice the level in question was 10\% higher.

Chart 3 - Years of police teaching staff service at local police training units

(as of 1 March, 2011)

\begin{tabular}{|c|c|c|c|c|c|c|c|c|c|c|c|}
\hline & & & & Leg & owo & & & Pila & & Slu & \\
\hline \multirow{6}{*}{$\begin{array}{l}\text { Years of service } \\
\text { at police training } \\
\text { units } \\
\text { (includes work on } \\
\text { didactic and non- } \\
\text { didactic posts) }\end{array}$} & $0-5$ & 49 & $33 \%$ & 52 & $33 \%$ & 27 & $\begin{array}{l}33.5 \\
\% \\
\end{array}$ & 21 & $33 \%$ & 37 & $35 \%$ \\
\hline & $6-10$ & 39 & $25 \%$ & 40 & $25 \%$ & 13 & $21 \%$ & 18 & $28 \%$ & 19 & $18 \%$ \\
\hline & $11-15$ & 22 & $26 \%$ & 41 & $26 \%$ & 18 & $29 \%$ & 13 & $20 \%$ & 35 & $\begin{array}{l}33.5 \\
\%\end{array}$ \\
\hline & $16-20$ & 17 & $12 \%$ & 19 & $12 \%$ & 4 & $6.5 \%$ & 7 & $11 \%$ & 13 & $\begin{array}{l}12.5 \\
\%\end{array}$ \\
\hline & $21-25$ & 2 & $2.5 \%$ & 4 & $2.5 \%$ & 0 & $0 \%$ & 5 & $8 \%$ & 1 & $1 \%$ \\
\hline & More than 25 & 1 & $1.5 \%$ & 2 & $1.5 \%$ & 0 & $0 \%$ & 0 & $0 \%$ & 0 & $0 \%$ \\
\hline
\end{tabular}

Source: Data of Personnel and Training Bureau, National Police Headquarters

6 The report Survey on European Police Education is the most thorough and assesses the potential of European police teaching staff in-depth. This report was drawn up by CEPOL. The research covered police education systems of 23 member states of the European Union. The report discusses among others the issue of such experience validity. Performing police job outside the training unit for the last five years was accepted as the criterion for such assessment (CEPOL, Survey on European Police Education and Training (SEPE). Final Report (Draft), Apeldoorn, Lisboa, Bramshill, 2006, p. 42). 
A qualitative aspect of work experience is also a very important issue. However, it has to be studied individually within a selection procedure for a particular teaching post. Moreover, it is not permanently linked with the number of years in service. In particular, during the selection process it may turn out that the quality of work experience of a candidate serving less than 10 years may be assessed higher than the other candidates whose number of years in service do clearly exceed the mentioned limit.

\subsection{Years of police teaching staff working experience}

According to the assumption accepted by the Team, rotational positions were to be created evolutionally, following a natural process of leaving the posts by police officers who retire or resign from their jobs due to other reasons. Taking into account the years in service of police teachers, it was assumed that the process would take at least several years. The number of police teaching staff members whose duration of service was of more than 20 years fluctuated between 20 to $30 \%$. It was only the Police School in Katowice where the process could be of a slightly longer duration because the school had relatively the youngest teaching staff as regards their years in service. In 2011, only $8 \%$ of police teachers were in service for more than 20 years.

Chart 4 - Police teaching staff members' years in service (as of 1 March 2011)

\begin{tabular}{|c|c|c|c|c|c|c|c|c|c|c|c|}
\hline & & \multicolumn{2}{|c|}{$\begin{array}{l}\text { Police } \\
\text { Academy }\end{array}$} & \multicolumn{2}{|c|}{$\begin{array}{l}\text { Police } \\
\text { Training } \\
\text { Centre }\end{array}$} & \multicolumn{2}{|c|}{$\begin{array}{l}\text { Police } \\
\text { School in } \\
\text { Katowice }\end{array}$} & \multicolumn{2}{|c|}{$\begin{array}{l}\text { Police } \\
\text { School in } \\
\text { Pila }\end{array}$} & \multicolumn{2}{|c|}{$\begin{array}{l}\text { Police } \\
\text { School in } \\
\text { Shupsk }\end{array}$} \\
\hline \multirow{6}{*}{$\begin{array}{l}\text { Police teachers' } \\
\text { years in service }\end{array}$} & $0-5$ & 1 & $0.5 \%$ & 1 & $0.5 \%$ & 0 & $0 \%$ & 0 & $0 \%$ & 3 & $3 \%$ \\
\hline & $6-10$ & 10 & $8 \%$ & 20 & $13 \%$ & 6 & $10 \%$ & 9 & $14 \%$ & 13 & $\begin{array}{l}12.5 \\
\%\end{array}$ \\
\hline & $11-15$ & 41 & $\begin{array}{l}31.5 \\
\%\end{array}$ & 43 & $27 \%$ & 22 & $\begin{array}{l}35.5 \\
\%\end{array}$ & 14 & $22 \%$ & 36 & $\begin{array}{l}34.5 \\
\%\end{array}$ \\
\hline & $16-20$ & 40 & $31 \%$ & 55 & $35 \%$ & 29 & $\begin{array}{l}46.5 \\
\%\end{array}$ & 22 & $\begin{array}{l}34.5 \\
\%\end{array}$ & 34 & $32 \%$ \\
\hline & $21-25$ & 15 & $12 \%$ & 26 & $\begin{array}{l}16.5 \\
\%\end{array}$ & 4 & $6.5 \%$ & 15 & $\begin{array}{l}23.5 \\
\%\end{array}$ & 13 & $12 \%$ \\
\hline & More than 25 & 23 & $17 \%$ & 13 & $8 \%$ & 1 & $1.5 \%$ & 4 & $6 \%$ & 6 & $6 \%$ \\
\hline
\end{tabular}

Source: Personnel and Training Bureau, National Police Headquarters

\section{Model of a rotational position - structural issues}

\subsection{Underlying assumptions}

The model presented by the Team has been developed based on the following assumptions:

- Police teaching staff should mainly consist of police officers who serve in police training facilities with no time limits (regular police officers). Officers temporarily serving in police training facilities (rotational staff) should only constitute the supplementation; 
- Due to a diversified number of police teaching posts in police training facilities, the number of rotational posts in all facilities should be specified in percentage terms;

- Rotational posts should be created with an appropriate balance maintained among particular groups of positions and they should not interfere with chances of promotion for regular teaching staff members, and

- Rotational posts should be created for a few years, considering natural fluctuation of the teaching staff.

\subsection{Number, source and time span for creating rotational positions}

The Team suggested that the number of rotational positions should constitute $10 \%$ of all police teaching posts in police training facilities. In the entire country, the number, as of 1 March 2011, would be 53. Due to the need to maintain competitiveness, the Team found it necessary to rank rotational posts relatively high in the hierarchy of all teaching positions.

Several factors seemed to call for the above-mentioned solution. First of all, the introduction of rotational posts in police educational institutions would be innovative in nature. As a result, it would be difficult to assess precisely the scale and risk of threats which could have an impact on its implementation. It seemed that $10 \%$ involvement of teaching personnel would be a safe indicator, which meant that a potential failure of the project would not result in the implementation of a teaching process. Moreover, the Team pointed out that after the first rotation cycle had been completed, it would be necessary to carry out the assessment of the project and, depending on its outcome, to increase, decrease or resign from rotational positions completely.

Considering social aspects, reaching $10 \%$ in the number of rotational positions was to be carried out evolutionally, following a natural process of leaving the posts by police officers. According to the Team's estimate it could take about 3 years.

\subsection{Legal formula of temporary employment}

Searching for a legal formula of temporary employment for police officers occupying teaching positions, the Team rejected the line of conceptual works aimed at the introduction of statutory changes in the relevant regulations. According to the Team, the implementation of such long-range solutions would be extremely time consuming and would possibly increase failure risks.

As a result, the suggested solution was merely organisational in nature. It was based on a specific way of financing rotational positions, involving the allocation of financial resources for educational institutions so as to rank higher a particular teaching post which was specified as a rotational one. This organisational solution was similar to the one introduced several years earlier by January 12, 2007 Act 
on The modernization of the Police, Border Guard, National Fire Service and the Government Protection Bureau in the years 2007-2009.7

The proposed solution was based on the following premises:

- After a teaching position has been vacated, the educational facility receives financial resources which allow for its transformation into a position of a senior lecturer and temporary increase in the service allowance to be received by a rotational teacher. The resources are granted for the duration of the rotation period. The Team is of the opinion that rotation period (increased financing) should not be shorter than three years and not longer than 5 years;

- There is a competition held with a view to select the best candidate for the rotational post;

- The selected candidate is appointed to the position and granted a permanent minimum service allowance and an increased temporary allowance;

- On completing the rotation period, the employee retires at their own request or is transferred to their local police unit, and

- Educational facility receives financial resources for another rotation period and launches a competition to select another candidate. If financial resources should not be granted, the rotational position returns to the original state.

\subsection{Competitiveness of rotational positions}

It should be assumed that police officers' interest in rotational positions will largely depend on their competitiveness against equivalent posts in the hierarchy of positions in local police units.

Competitiveness of positions can be examined using a number of aspects. This applies especially to qualification and competency requirements, scope of tasks and obligations, responsibilities and offered financial conditions. Following the analysis of legislation regulating the matters in question, the Team reached a general conclusion that the classification of particular teaching posts was attractive and adequate from the point of view of work evaluation.

Unfortunately, the distorted competitiveness of teaching and operational posts occurred with reference to the amount of service allowances. As regards this criterion, the situation of a senior lecturer with Police Schools in Katowice, Slupsk and Legionowo is far worse than that of an equivalent expert employed in the respective local police garrison. Only in case of the Police Academy in Szczytno and Police School in Pila, the competitiveness of senior lecturers' service allowances was similar to allowances of experts with respective local police units.

In the Team's opinion, ensuring attractiveness of rotational positions (raising their competitiveness) would require increase in service allowance by at least one third in comparison with analogous positions in local police units. On the one hand, it would be a form of compensation for increased costs which are incurred temporarily by a police officer working outside his/her permanent residence, and on the other one, it would be a form of an incentive connected with the prospects for a relatively higher retirement pension.

7 OJ. Vol. 25, entry 213. 


\subsection{Advantages and disadvantages}

The solution proposed by the Team was, in many respects, regarded as controversial. By comparison of its most significant advantages and disadvantages, the former are:

1. Possibility of recruiting a trainer with up-to-date professional experience, and consequently updating the teaching contents;

2. Enhancing the effectiveness of the teaching process;

3. Increasing the authority of teachers and trainers working in police schools. Job-related issues would be taught by teachers with incomparably bigger experience than trainees;

4. Creating the potential for the best police officers with long experience to finish their career with decent financial parameters.

Unfortunately, the Team's work revealed a number of serious drawbacks of the proposed solution, the most important of which are:

1. Complicated and time consuming procedure, which would have to be put in place in order to formally give a special status to the rotational position;

2. Difficulties that may appear in the situation when after the rotation period a police officer does not submit a report to claim retirement benefits. In such case, a post at the local police station should be found, where the officer ought to be transferred ex officio. Such process, however, is highly cost-consuming;

3. Retirement of several rotational officers during the period of one year may be a significant burden on the budget of the training unit in connection with the necessity to pay out retirement bonuses;

4. Separating a group of considerably better paid teachers in the training unit may lead to inside tensions. Frustrations that emerge consequently may result in diverse behaviours of the personnel, which may influence both the quality of teaching process and the ability to manage the unit (e.g., discriminating behaviours towards rotational personnel; decrease in work efficiency of full time personnel, including the management; increase in the number of anonymous notifications concerning alleged irregularities in unit's management);

5. Increasing the service allowance for a rotational teacher by the amount proposed by the Team would lead to a situation in which they would be higher than the position allowances in some of the school's managerial posts. Having noticed the possibility of serious problems which may arise in case of implementation of 'a rotational post', the Team offered to develop an alternative model of 'an associate lecturer'.

\section{Associate lecturer as an alternative solution}

It has become a standard that police training units are expected to implement highly-specialised forms of teaching. It usually requires teaching staff with high level of knowledge and skills in the strictly determined narrow specialisation. At the same time, the speed at which the modus operandi of perpetrators is changing causes that in order to conduct this kind of trainings, constant and direct contact with the police practice is required. It concerns, especially, the issue of criminal application of modern technologies.

[104] NBP • Žurnal za kriminalistiku i pravo 
In such cases, it has become a good practice to invite police specialists from local police units as teaching personnel for particular classes that are conducted in police training units (so-called 'associate lecturers'). Unfortunately, during the period of the Team's work, the phenomenon had a marginal character. Above all, the issue of supporting the teaching process by local police units did not have a central legal regulation. As a consequence, each of the local units pursued its own policy in this regard, and its implementation depended not only on the will of cooperation of the police specialist from the local police unit, but also on the supervisor's consent to such support.

At this point, an example of such regulation concerning the institution of 'an associate lecturer' needs to be presented. In this respect, the rich practice of the Police Academy in Szczytno will be of help. The process of supporting the teaching personnel by officers from local police units dates back to 2005. During the first years of its functioning it took form of unformalised practice. It was not until 2008 that the issue was regulated by the Commandant-Rector's Decision. ${ }^{8}$

In accordance with the above-mentioned internal managing act, not only a police officer or a civilian working for police, but also a person outside this formation (e.g., an officer of other public service responsible for security and public order or a representative of a non-governmental organization) may become an associate lecturer. In practice, this group consists mainly of police officers who are on duty at police stations.

An associate lecturer needs to posses high professional and teaching qualifications, as well as rich professional experience useful in the respect of the character of implemented tasks. Responsibility for searching and nominating candidates for associate lecturers rests on persons who manage the teaching unit at the Academy. These people have wide knowledge not only regarding their teaching tasks which are implemented by the units they supervise, but also regarding their personnel potential. Therefore, burdening the people with a duty to diagnose needs in the scope of supporting the teaching process by associate teachers seems to be fully justified.

Appropriate preparation of officers from the police stations who support the teaching process at the Academy is of great importance. The guardian of an associate teacher is responsible for the implementation of this task. It is determined by the head of the appropriate didactic unit among the subordinated teachers. The tutor must have high professional qualifications and teaching experience. The tutor is supposed to offer the associated lecturer any kind of help related to the stay at the Academy as well as realization of the didactic process. In justifiable cases, especially when the associate lecturer does not have required didactic qualifications, the tutor runs a crash course on the methodical and organisational basis of the didactic process. Furthermore, if there is a need, the tutor also organises a presentation, where the lecturer has to observe a sample class. The tutor can also apply to the head of the appropriate unit of organisation of the teaching process in order to get professional help in the field of methodology of teaching.

8 Commandant-Rector's Decision of 23 June 2008 No. 75/2008 on support of teaching process at the Police Academy in Szczytno by associate lecturers. 
According to the collected experience so far, it can be pointed out, that the associatelectures are first of all directed to run classes in form of exercises, simulations and presentations. With the reference to transfer of knowledge, these forms give opportunity to lead discussion in a relatively inconsiderable group of students and in relation to the taught skills - they also enable any correctness of their behaviour. Therefore, from the point of view of using the professional teacher's experience, they are definitely more effective than lectures. It is also not meaningless, that in order to carry on lectures a very good pedagogical preparations as well as great didactic experience are required.

The participation of police associate teachers in the process of teaching cannot have a negative influence on the realization of tasks assigned to those police officers in their police units. Simultaneously - according to the need of rational acting - their stay at the Academy should be effectively used. Taking the above into consideration, the process of decision-making has some limitations in this matter. Most of all, the recommended time of a single stay of an associate lecturer at the Academy should not be longer than 5 working days. Simultaneously, such a lecturer should be assigned to have at least 4 teaching units a day. Furthermore, the working time of an associate lecturer at the Academy should not exceed the limit of 100 teaching units per year.

The essential question, which should be mentioned, is the fact that the decision to become an associate lecturer is of free matter. Enrolment of a police officer into the register of associate lecturers at the Academy takes place after his or her permission. The candidate for an associate lecturer fills in a special informative form. This paper also includes additional data concerning degree, any qualifications, and period of service, pedagogical education and didactic experience as well as accomplished trainings, in relation to which the police officer agrees to support the training unit. The database set up in this way is used for designation of people, who in certain cases may supplement the deficiency of staff at the Academy.

The gratuitousness of participation of associate lectures in the teaching process is also manifested in this way that their every arrival at the Academy is always being consulted with them in advance. They also get a project of a programme of their stay, which includes full information concerning the date and extend of their participation in the teaching process at the Academy. It is worth mentioning that a permission of a police officer himself on giving support is not enough. It is also indispensable to gain the commander's permission for delegation to the Academy. At that time the police officer is being released of his duties at the vernacular unit.

According to the valid law regulations, a police officer of a local police unit, who works as an associate lecturer cannot be paid by the Academy for his job because he is still subordinated to the commander of his police force. However, his superior may consider the fact of performing additional activity by the officer for the police training unit and in such case he might - making the use of means being at the disposal of the local police unit - grant the subordinated officer a financial award.

The fact of normalization of the 'associate lecturer' institution within the particular training units does not mean that it is really being used. The data collected by the Team revealed that in 2010 the Police School in Słupsk did not make use of help of the associate lecturers at all. Practically, the Police School in Katowice 
also did not make use of it. The remaining three training units made use of such support, however only at the level of $1.3 \%-1.5 \%$ of the overall number of teaching hours, which had been realized in 2010. It is also worth mentioning the differential average number of hours, which had been realized by a statistical associate lecturer. Despite the similar level of support, which was given to the training units by this group, the average number of hours for one associate lecturer was in Piła - 9, in Szczytno - 33 and in Legionowo - 73.

Chart 5 - Police officers from local police units conducting classes at the police training centres in 2010

\begin{tabular}{|l|c|c|c|c|}
\hline $\begin{array}{l}\text { Police Training } \\
\text { Centre }\end{array}$ & $\begin{array}{c}\text { Number of } \\
\text { associate } \\
\text { teachers }\end{array}$ & $\begin{array}{c}\text { Number of classes } \\
\text { conducted by } \\
\text { associate teachers }\end{array}$ & $\begin{array}{c}\text { Percentage of classes } \\
\text { conducted by } \\
\text { associate teachers in } \\
\text { the total number of } \\
\text { classes conducted at } \\
\text { the training centre }\end{array}$ & $\begin{array}{c}\text { Average number of } \\
\text { classes per one } \\
\text { associate teacher }\end{array}$ \\
\hline $\begin{array}{l}\text { Police } \\
\text { Academy in } \\
\text { Szczytno }\end{array}$ & 34 & 1122 & $1.32 \%$ & 33 \\
\hline $\begin{array}{l}\text { Police Training } \\
\text { Centre in } \\
\text { Legionowo }\end{array}$ & 26 & 1899 & $1.45 \%$ & 73.03 \\
\hline $\begin{array}{l}\text { Police School } \\
\text { in Katowice }\end{array}$ & 2 & 79 & $0.17 \%$ & 39.5 \\
\hline $\begin{array}{l}\text { Police School } \\
\text { in Pila }\end{array}$ & 60 & 541 & $1.27 \%$ & 9.01 \\
\hline $\begin{array}{l}\text { Police School } \\
\text { in Shupsk }\end{array}$ & 0 & 0 & $0 \%$ & 0 \\
\hline
\end{tabular}

Source: Data provided by the police training centres

After the analysis of the data gathered, the Team came to a conclusion that associate teachers can strongly support the police training centres. Concentrating on filling the training centres with police officers who have relevant and current professional experience, the model of "the associate teacher" could support the model of "a rotational position" or - in case of rejecting that concept - it could be an independent solution. However, in order to reach the goal there should be some organisational changes introduced. According to the Team, in order to assign a real meaning to the idea of associate teachers the following had to be done:

- Implement a central regulation which would standardize the process of supporting police training centres with experts from local police units. It would be helpful to have internal regulations, which were prepared by training centres;

- Award a certain number of points to associate teachers. The points could later be used by the candidates taking part in a competition for managerial posts in the police. However, the points would be awarded to those associate teachers who conducted a certain number of classes (e.g., at least 200 classes within 2 years). 


\section{Conclusion}

The proposals of the Team regarding the support of the police training centres within the framework of "a rotational position" and "an associate teacher" were submitted to receive an opinion from the police training centres' chiefs, selected Regional Police Chiefs (from the regions where the training centres are situated) as well as the director of the Finance Bureau and director of Personnel and Training Bureau of the National Police Headquarters.

Respondents unanimously agreed that experience of a police teacher is one of the crucial elements influencing the efficiency of training and professional development in the police training centres. Looking from this perspective, the initiative of recruiting police officers with rich and relevant professional experience to teach in the police training centres was an idea approved by all the respondents. However, the respondents did not share the same view regarding the way the initiatives planned to be developed.

As it concerns "the rotational position" practically, all the respondents highlighted the scope of threats pointed out in the report. They mainly referred to the organisational and financial problems as well as social ones. It has been emphasized that the process of transforming the teaching positions into rotational ones is not only time consuming and costly, but also may cause the instability of the position/vacancy structure in the police training centres. It has also been estimated that the solutions proposed in the report may generate additional financial costs due to e.g., changing the place of duty, dismissing from duty or housing benefits. As a vital threat there has also been presented that preferential aspect of rotational positions may be a source of tension which may result in the poor quality of the teaching process. However, a full support was given to the proposal of developing the idea of "an associate teacher".

Internal consultations within the organisation were of primary importance for the National Police Chief to reject the model of "a rotational position". At the same time, he introduced changes which were supposed to support a competitive model. First of all, they were related to the National Police Chief's Instructions from 1 January 2009, which were attached to a document called "Ogólny tryb i zasady przeprowadzania postępowań kwalifikacyjnych na wybrane stanowiska służbowe w Policji" (General methods of conducting qualifying procedures for selected posts in the police). The above-mentioned document provided that open competition would become the standard method for recruitment for all management positions within the Polish Police; additionally, a guide has been devised for all persons involved in the recruitment procedure. It includes advice and guidelines for the grading process, methodology of creating grading-tools, the method and rules to be applied for each stage of the recruitment process, as well as some specimens of the documents used. The recruitment outcome depends on the overall score that each participant has gained at each of the recruitment process stages. On 14 November 2011, the National Police Chief introduced changes, according to which a candidate applying for a particular management position may be given additional 2 points for his or her work experience, providing he or she fulfils the requirement of having at least 3-year-experience in conducting classes as "an associate teacher." 
Furthermore, on 7 October 2011, the Polish Police Chief published "Wytyczne w sprawie kierowania wniosków nagrodowych do Komendanta Głównego Policji" (Guidelines on directing motions of awards to the National Police Chief). 9 According to this document, an associate teacher can receive the Police Chief's financial reward if "he has conducted at least 70 hours of didactic classes in the Police Academy in Szczytno or other police school."

In assessing the introduced changes and how they have influenced the functioning of the 'associate lecturer' model, we should relate to the data comparison regarding the number of associate lecturers and the number of classes taught. To illustrate this, the example of the Police Academy in Szczytno will be used.

Chart 6 - List of didactic classes held at the Police Academy in Szczytno by associate lecturers between years 2010-2013

\begin{tabular}{|c|c|c||}
\hline Calendar year & $\begin{array}{c}\text { Number of associate lecturers } \\
\text { conducting classes }\end{array}$ & Number of hours taught in class \\
\hline 2011 & 33 & 750 \\
\hline 2012 & 20 & 1197 \\
\hline 2013 & 67 & 1937 \\
\hline January - September)
\end{tabular}

Source: Police Academy in Szczytno

The juxtaposition of the data sourced from the Police Academy in Szczytno clearly proves that after introducing changes to the competition procedures, the number of associate lecturers in the first three quarters of 2013 has doubled compared to 2011, and has tripled compared to 2012. The number of classes conducted by associate lecturers has increased as well by $40 \%$ compared to 2012 and by more than $60 \%$ compared to 2011 . What should be noted is that the data comparison does not entail the third quarter of 2013, so we can envisage those differences shown above to rise even further.

The observations made hitherto point to the conclusion that employing the 'associate lecturer' model is the easiest method of transferring the skills and knowledge stemming from front-line officers' experience to police schools. At the same time, the introduction of a coherent mechanism of profiting, which a frontline officer will gain upon commencing didactic work, bears crucial importance for increasing the effectiveness of the process. Those can equally well be financial profits (i.e., financial motivational rewards, special financial didactic bonuses, prizes, and extra holiday days) and non-financial profits within the agency. The effectiveness of the latter is clear in the Polish Police.

9 Web source: http://isp.policja.pl/download/12/1871/PoradnikdoOgolnegotrybu1052012.pdf (Access date: 19.10.2013). 


\section{References}

1. Berg, B. L; Policing in Modern Society. Boston: Butterworth/Heinemann, 1999.

2. Bogdalski, P; Сотрудники отделений полиции в качестве внештатньх преподавателей в высиих полицейских учебных заведениях. In: Вестник Академии МВД Республики Беларусь, Академия МВД Республики Беларусь, Мінск, № 2 (22), 2011.

3. Bogdalski, P; Warunki efektywności szkolenia podstawowego w kontekście procesu kształtowania kadrowego potencjału Policji. In: Bezpieczeństwo. Teoria i Praktyka, Krakow University im. Frycza Modrzewskiego, Kraków, No. 1-2, 2009.

4. Bogdalski, P; Survey on the Teaching Staff of European Police Colleges, In: Internal Security, Police Academy, Szczytno, No 1, 2009.

5. CEPOL, Survey on European Police Education and Training (SEPE). Final Report (Draft), Apeldoorn, Lisboa, Bramshill, 2006.

6. Marć, M; Binkowska-Bury, M; Penar-Zadarko, B; Wymagania stawiane nauczycielom zawodu pielęgniarstwa - przeszłość, teraźniejszość, przyszłość. In: Problemy Pielęgniarstwa, Nr 16, 2008.

7. Ministerstwo Edukacji Narodowej, Kształcenie zawodowe i ustawiczne, Fundacja Fundusz Współpracy, Warszawa, 2010. 